\title{
FACTUAL NUTRIIION OF MODERN SCHOOLCHILDREN AND ITS IMPACT ON MENTAL EFFICIENCY AND FATIEUE
}

\author{
Hozak S.V., Yelizarova O.T., Stankevytch T.V., Parats A.M.
} ФАКТИИНЕ ХАРЧУВАННЯ СУЧАСНИХ ШКОЛЛРЯВ ТА ЙОГО ВПЛИВ НА РОЗУМОВУ ПРАLЕЗДАТННСТЬ I ВТОМУ

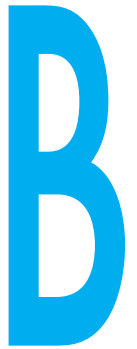

ГОЗАК С.В., ЄЛІЗАРОВА О.Т., СТАНКЕВИЧ Т.В., ПАРАЦ А.М. ДУ «Інститут громадського здоров'я ім. О.М. Марзєєва НАМН України», м. Київ

УДК 613.22:613.955

Ключові слова: харчування школярів, діти середнього та старшого шкільного віку, розумова працездатність, втома. ідомо, що харчування є одним з провідних факторів, що впливають на здоров'я та працездатність дітей. В останні два десятиліття суттєво змінилися харчові технології, асортимент продуктів, харчові смаки та вподобання школярів, організація та режими харчування, що потребує нових наукових досліджень [1, 2]

Водночас трансформаційні зміни у суспільстві призводять й до змін способу життя учнів, а також інтенсифікації навчального процесу у закладах освіти, що, у свою чергу, впливає на їхнє харчування.

Попередніми дослідженнями було виявлено певні обмеження необхідних нутрієнтів у раціонах харчування учнів. У раціонах дітей молодшого шкільного віку спостерігається дефіцит білків, вітамінів груп В, C, ніацину, кальцію, мікроелементів, що зумовлено низьким

ФАКТИЧЕСКОЕ ПИТАНИЕ СОВРЕМЕННЫХ ШКОЛЬНИКОВ И ЕГО ВЛИЯНИЕ НА УМСТВЕННУЮ РАБОТОСПОСОБНОСТЬ И УТОМЛЕНИЕ Гозак С.В., Елизарова Е.Т., Станкевич Т.В., Парац А.Н. ГУ «Институт общественного здоровья им. А.Н. Марзеева НАМН Украины», г. Киев

Цель исследования - гигиеническая оценка фактического питания учащихся и определение его влияния на умственную работоспособность детей среднего и старшего школьного возраста. Материалы и методы. Особенности питания изучали путем анкетирования 462 школьников 5-11 классов г. Киева. Умственную работоспособность исследовали с помощью корректурных проб с последующей статистической обработкой всех полученных данных. Результаты. Фактическое питание современных школьников характеризуется недостаточным потреблением таких продуктов, как мясо, сливочное масло, яйца, молоко у 22\% детей, рыбы и морепродуктов - у 60\% детей. В целом неудовлетворительное питание характерно для 19\% учащихся среднего и $16 \%$ старшего школьного возраста. Результаты интегральной оценки показали, что с 5-го по 9-й класс увеличивается количество детей с неудовлетворительным питанием и уменьшается с оптимальным $(p<0,001)$. Установлена связь повышения продуктивности умственной работоспособности с ростом интегральной оценки питания $\left(r_{s}=0,12 ; p<0,001\right)$. Изолированный вклад фактора «питание» на продуктивность умственной работоспособности составляет $(7,3 \pm 0,4), p<0,01)$. Вероятность высокого уровня утомления школьников в 1,3 раза выше при неудовлетворительном питании, чем при оптимальном $(p<0,05)$.

Ключевые слова: питание школьников, дети среднего и старшего школьного возраста, умственная работоспособность, утомление.

() Гозак С.В., Єлізарова О.Т., Станкевич Т.В., Парац А.М. СТАТTЯ, 2017. 
Таблиця 1 Анкета «Режим харчування учнів загальноосвітніх навчальних закладів»

\begin{tabular}{|c|c|c|c|c|}
\hline \multirow{3}{*}{\multicolumn{5}{|c|}{$\begin{array}{c}\text { ДУ «Інститут громадського здоров”я ім. О.М. Марзєєва НАМН України» } \\
\text { Анкета «Харчування учнів загальноосвітніх навчальних закладів» }\end{array}$}} \\
\hline & & & & \\
\hline \multirow{2}{*}{\multicolumn{5}{|c|}{$\begin{array}{ll}\text { Дата заповнення анкети } & 20 \mathrm{p} . \\
\text { Ім'я, прізвище учня } & \end{array}$}} \\
\hline & & & & \\
\hline \multicolumn{2}{|l|}{ Дата народження $\quad$ Стать учня: Ч ж } & \multicolumn{2}{|c|}{ Клас: } & \\
\hline \multicolumn{5}{|c|}{ Як часто ти використовуєш у своєму раціоні харчування наступні продукти? } \\
\hline Продукти харчування & $\begin{array}{c}\text { Що- } \\
\text { ден- } \\
\text { но }\end{array}$ & $\begin{array}{c}2-3 \\
\text { рази } \\
\text { на тиж- } \\
\text { день }\end{array}$ & \begin{tabular}{|c|}
$2-3$ \\
рази \\
на \\
місяць
\end{tabular} & $\begin{array}{l}\text { Май- } \\
\text { же } \\
\text { ніко- } \\
\text { ли }\end{array}$ \\
\hline Овочі (картопля, буряк, морква, капуста та ін.) & 4 & 3 & 2 & 1 \\
\hline Фрукти (яблука, банани, груші, апельсини та ін.) & 4 & 3 & 2 & 1 \\
\hline Ягоди (малина, полуниця, смородина та ін.) & 4 & 3 & 2 & 1 \\
\hline М'ясо (свинина, яловичина, м'ясо птахів та ін.) & 4 & 3 & 2 & 1 \\
\hline Субпродукти (печінка, серце та ін.) & 4 & 3 & 2 & 1 \\
\hline Яйця & 4 & 3 & 2 & 1 \\
\hline Молоко & 4 & 3 & 2 & 1 \\
\hline Кисломолочні продукти (сир, йогурт, кефір) & 4 & 3 & 2 & 1 \\
\hline $\begin{array}{l}\text { Риба і морепродукти (мідії, ікра, креветки, } \\
\text { морська капуста та ін.) }\end{array}$ & 4 & 3 & 2 & 1 \\
\hline Ковбаси, сосиски & 4 & 3 & 2 & 1 \\
\hline Хліб, бублики, сухарі & 4 & 3 & 2 & 1 \\
\hline Солодощі (цукор, цукерки, халва та ін.) & 1 & 4 & 3 & 2 \\
\hline Вершкове масло & 4 & 3 & 2 & 1 \\
\hline Мед & 4 & 3 & 2 & 1 \\
\hline Варення & 4 & 3 & 2 & 1 \\
\hline Какао & 4 & 3 & 2 & 1 \\
\hline Чай & 4 & 3 & 2 & 1 \\
\hline Кава & 1 & 2 & 3 & 4 \\
\hline Здоба, конд. вироби (торти, пиріжки, печиво та ін) & 1 & 4 & 3 & 2 \\
\hline Солодкі газовані напої & 1 & 2 & 3 & 4 \\
\hline Чіпси, солоні сухарики & 1 & 2 & 3 & 4 \\
\hline Майонез, кетчуп & 1 & 2 & 3 & 4 \\
\hline Жувальна гумка & 1 & 2 & 3 & 4 \\
\hline Гострі приправи, спеції (перець, гірчиця, хрін) & 1 & 2 & 3 & 4 \\
\hline \multicolumn{5}{|c|}{ Як часто ти їси наступні страви? } \\
\hline Страви & $\begin{array}{c}\text { Що- } \\
\text { ден- } \\
\text { но }\end{array}$ & $\begin{array}{c}\text { Кілька } \\
\text { разів } \\
\text { на тиж- } \\
\text { день } \\
\end{array}$ & \begin{tabular}{|c|}
$1-2$ \\
рази \\
на \\
місяць \\
\end{tabular} & \begin{tabular}{|c|} 
Рідко \\
або \\
ніко- \\
ли \\
\end{tabular} \\
\hline Гарячі перші страви (суп, борщ) & 4 & 3 & 2 & 1 \\
\hline Каші & 4 & 3 & 2 & 1 \\
\hline Каші молочні & 4 & 3 & 2 & 1 \\
\hline Картопляні гарніри & 4 & 3 & 2 & 1 \\
\hline М'ясні страви (котлети, битки, фрикаделі) & 4 & 3 & 2 & 1 \\
\hline Рибні страви & 4 & 3 & 2 & 1 \\
\hline Овочеві рагу & 4 & 3 & 2 & 1 \\
\hline Овочеві салати з олією & 4 & 3 & 2 & 1 \\
\hline Салати з майонезом & 1 & 2 & 3 & 4 \\
\hline Консервовані (мариновані, квашені) овочі & 4 & 3 & 2 & 1 \\
\hline $\begin{array}{l}\text { Страви з борошна (макарони, пельмені, } \\
\text { вареники, млинці) }\end{array}$ & 1 & 4 & 3 & 2 \\
\hline Фаст-фуд (бургери, нагетси, шаурма та ін.) & 1 & 2 & 3 & 4 \\
\hline
\end{tabular}

групи продуктів, що можуть вживатись у помірній кількості 2-3 рази на тиждень без шкоди для здоров'я (II група) віднесли цукерки, халву, мед, варення, чай, какао, каву. До некорисних продуктів, кулінарних виробів та напоїв (III група) відносили здобу та кондитерські вироби (торти, пиріжки, тістечка, печиво), ковбасні вироби, солодкі газовані напої, чіпси, сухарики, соуси (майонез, кетчуп), жувальну гумку. Оцінку харчування проводили за 4-бальною шкалою відповідно до ключа анкети.

Отриману інформацію оцінювали як середнє арифметичне балів кожної групи та в цілому, виражене у відсотках за формулою:

$$
\mathrm{IO}=\left(\frac{1}{k} \sum_{i=1}^{k}\left(n_{i}\right)-1\right) \times 100,
$$

де $\mathrm{IO}$ - інтегральна оцінка харчування;

$\mathrm{n}_{\mathrm{i}}$ - бальна оцінка і-того показника;

k - кількість показників, за якими оцінюється харчування.

Чим ближче отримана оцінка до 100\%, тим більше фактичне харчування відповідає гігієнічним рекомендаціям.

За допомогою стандартного відхилення розроблено критерії комплексної оцінки харчування: інтегральний показник 71,4-100\% - оптимальний рівень харчування, 45,8-71,3\% - задовільний, 0-45,7\% - незадовільний.

Дослідження розумової працездатності проведене шляхом натурного експерименту за методом коректурної проби з використанням таблиць Анфімова з подальшим розрахунком ступеня втоми кожного учня за класичною методикою Антропової М.В. [7].

Вивчення продуктивності та точності розумової працездатності школярів проводили шляхом порівняння «стартового» (на початку другого уроку) рівня кількості переглянутих знаків та зроблених помилок 3 відповідними показниками, визначеними після кожного уроку.

Силу ізольованого впливу факторів визначали як частку міжгрупової варіації у 
such foodstuffs as meat, butter, eggs, dairy produce in $22 \%$ of the children, fish and sea products in $60 \%$ of the children. In general the malnutrition is typical for $19 \%$ of middle-age schoolchildren and $16 \%$ of senior age ones. Results of integral assessment showed that a number of children with malnutrition increased and decreased with optimum nutrition from 5 -th to 9 -th grades $(p<0,001)$. A connection of the increase of the productivity of mental efficiency with a growth of integral assessment of nutrition was established $\left(r_{s}=0.12 ; p<0.001\right)$. Isolated contribution of "nutrition" factor in the productivity of mental efficiency is $(7.3 \pm 0.4) \%, p<0.01)$.

Probability of the high level of fatigue in the schoolchildren is 1.3 times as high at malnutrition than at the optimum nutrition $(p<0.05)$.

Keywords: nutrition of schoolchildren, middle-age and senior school age children, mental efficiency, fatigue.

Results. Factual nutrition of modern schoolchildren is characterized by the insufficient consumption of

загальному варіюванні результуючої ознаки [8].

При обробці даних були використані статистичні методи аналізу за допомогою програми STATISTICA 8.0.

Результати та їх обговорення. За результатами анкетування виявлено, що споживання хліба, злаків, овочів, фруктів $€$ відповідним для більш ніж 90,0\% учнів середнього та старшого шкільного віку. Водночас 21,6-30,2\% учнів обстеженої когорти мають обмеження у раціоні таких продуктів, як м'ясо, вершкове масло, яйця та молоко (рис. 1). Найбільший дефіцит спостерігається щодо споживання риби та морепродуктів. Частка дітей, які споживають рибу лише 1-2 рази на місяць або зовсім не споживають, становить (60,3 \pm $1,0) \%$ серед учнів середньої вікової групи та $(59,4 \pm 5,0) \%$ старшої.

Порівняння споживання продуктів учнями середньої та старшої вікової групи показало відмінності споживання м'яса та субпродуктів $\left(\chi^{2}=11,3\right.$; $\mathrm{p}<0,001)$, а також хліба та хлібопродуктів $\left(\chi^{2}=6,7 ; p<0,01\right)$ (рис. 1). Частка дітей, які споживають рекомендовану кількість м'яса, серед старшокласників більша на $17,1 \%$, ніж серед учнів середнього шкільного віку.

Щодо продуктів II групи, привертає увагу те, що $(46,3 \pm$ $2,6) \%$ дітей середнього шкільного віку та $(35,4 \pm 4,9) \%$ старшого шкільного віку щоденно споживають солодощі, $(23,1 \pm$
$2,2) \%$ та $(18,8 \pm 4,0) \%$ - каву. Проте частка дітей, які вказали, що не споживають каву, серед учнів середнього шкільного віку на 12,4\% більша, ніж серед старшокласників $(\mathrm{t}=2,3$; $p<0,05)$.

Майже ніколи не споживають каву $(30,2 \pm 4,7) \%$ старшокласників, мед - $(17,7 \pm 3,9) \%$, какао - $(33,3 \pm 4,8) \%$, варення - $(22,9 \pm 4,3) \%$, солодощі - $(5,2$ $\pm 2,3) \%$.

Щоденно варення серед старшокласників споживають $(7,3 \pm 2,7) \%$ дітей, що на $11,1 \%$ менше, ніж серед учнів середнього шкільного віку ( $t=3,3$; $\mathrm{p}<0,01)$.

Також серед старшокласників на 11,4\% менше дітей, які щодня споживають какао $(\mathrm{t}=$ $3,4 ; p<0,01)$

\section{Рисунок 1}

Частка дітей середнього та старшого шкільного віку з недостатнім споживанням харчових продуктів I групи, \%

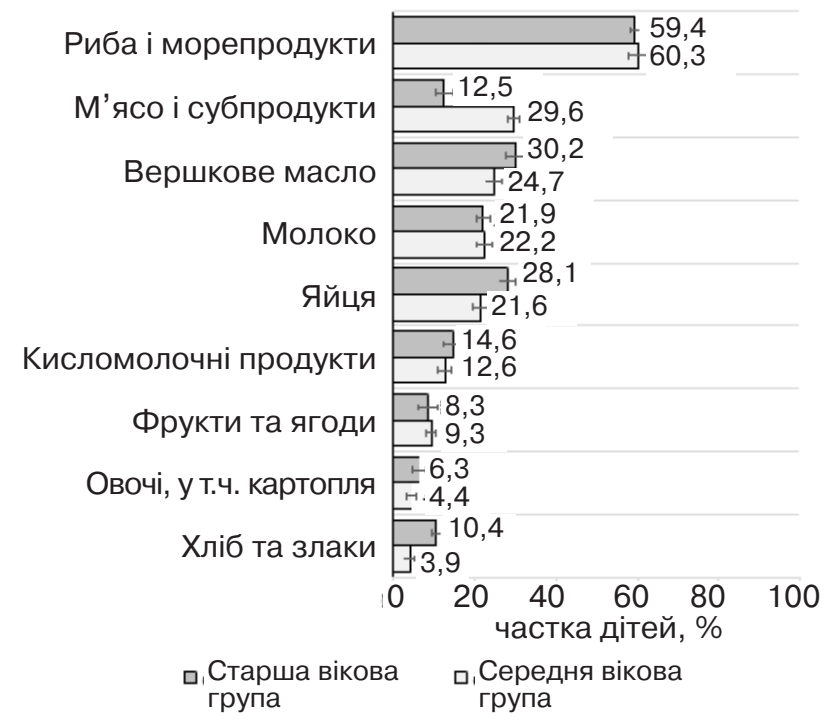

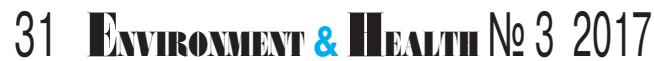
Частка дітей шкільного віку, які щоденно та часто споживають продукти і напої III групи, \%

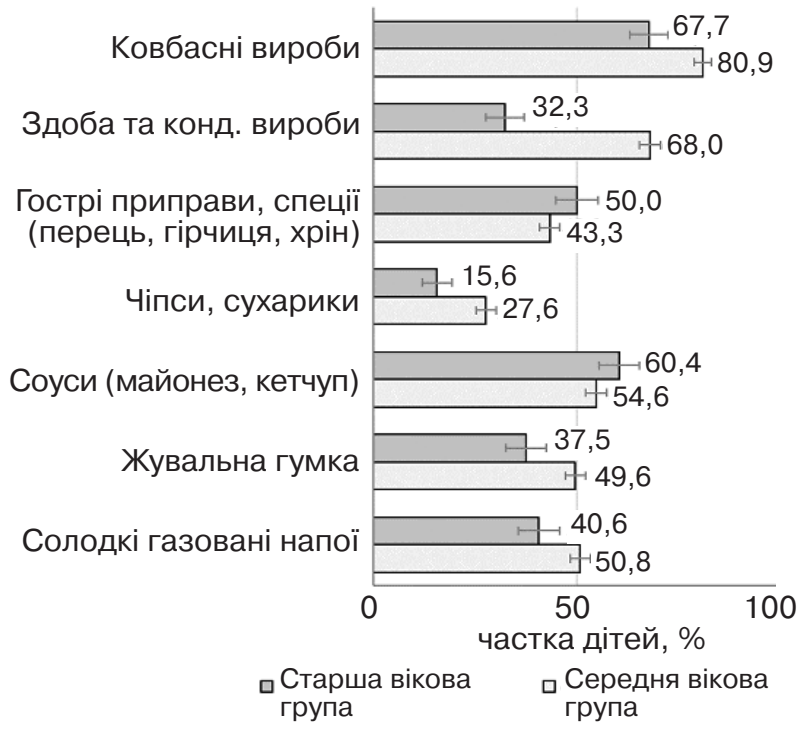


$13,2 \%(t=2,4 ; p<0,05)$, жувальної гумки - на $12,1 \%(\mathrm{t}=2,1$; $\mathrm{p}<0,05)$, чіпсів/сухариків - на $12,0 \%(t=2,7 ; p<0,05)$.

Встановлено, що значна частка школярів щоденно або часто споживає разом декілька продуктів III групи, зокрема $(81,6 \pm 3,0) \%$ дітей разом 3 солодощами щоденно споживають здобу або кондитерські вироби, $(84,5 \pm 2,8) \%$ - ковбасні вироби, $(44,1 \pm 3,8) \%-$ чіпси або сухарики, $(40,5 \pm 3,8) \%-$ майонез, кетчуп, $(34,5 \pm 3,7) \%$ - солодкі газовані напої. Це підвищує ризик негативного впливу на дитячий організм.

Аналіз споживання дітьми готових страв показав, що у загальній групі дослідження частка дітей, які щодня або декілька разів на тиждень споживають гарячі перші страви, становить $(89,1 \pm 1,5) \%$, каші $(79,5 \pm 1,9) \%$, картопляні гарніри - $(82,7 \pm 1,8) \%$, м'ясні страви - $(83,1 \pm 1,8) \%$, рибні страви - $(44,9 \pm 2,3) \%$ (з них 8,2\% споживають рибні страви майже щодня), овочеві рагу - $(38,1 \pm$ $2,3) \%$, свіжі овочеві салати 3 олією - $(67,9 \pm 2,2) \%$, салати 3 майонезом - $(39,1 \pm 2,3) \%$, консервовані овочі - $(47,3 \pm$ $2,3) \%$, страви 3 борошна $(76,6 \pm 2,0) \%$.

віком $35,7 \%$ (t $=6,7$ $\mathrm{p}<0,001)$, ковбасних виробів -

Розподіл учнів середнього шкільного віку

Рисунок 3 за інтегральною оцінкою харчування $(p<0,05)$, \%

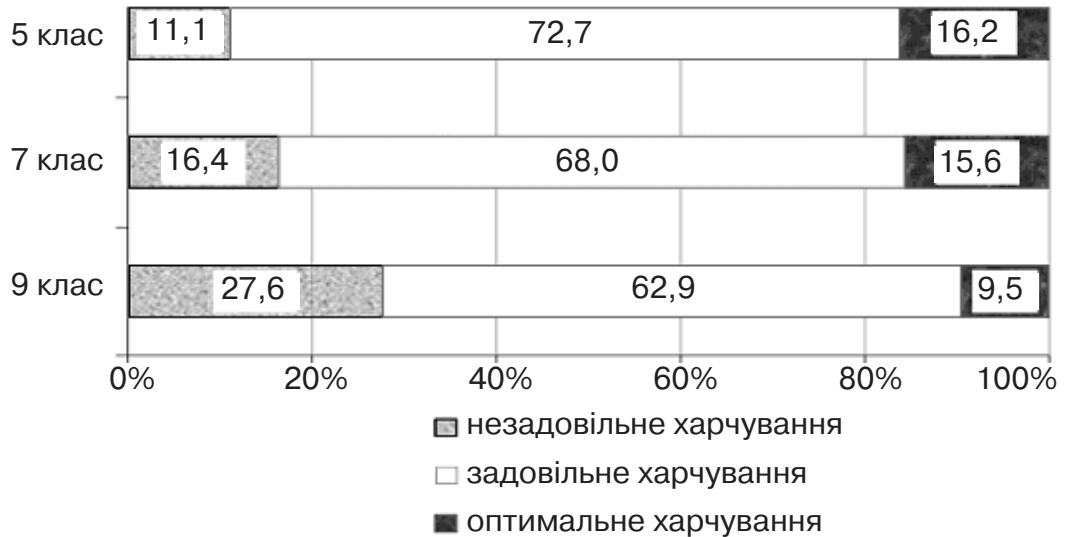

Показники розумової працездатності учнів залежно від інтегральної оцінки харчування ( $\mathbf{M} \pm \mathbf{m})$

\begin{tabular}{|c|c|c|c|c|}
\hline $\begin{array}{c}\text { Оцінка } \\
\text { харчування }\end{array}$ & $\begin{array}{c}\text { Коефіцієнт } \\
\text { продуктив- } \\
\text { ності }\end{array}$ & $\begin{array}{c}\text { Об'єм пра- } \\
\text { цездатності }\end{array}$ & $\begin{array}{c}\text { Середня точ- } \\
\text { ність праце- } \\
\text { здатності }\end{array}$ & $\begin{array}{c}\text { Кількість } \\
\text { помилок на } \\
500 \text { знаків }\end{array}$ \\
\hline Незадовільне & $27,4 \pm 0,6$ & $311,9 \pm 6,6$ & $4,7 \pm 0,3$ & $9,7 \pm 0,4$ \\
\hline Задовільне & $27,9 \pm 0,3$ & $320,3 \pm 2,8$ & $5,2 \pm 0,1$ & $10,0 \pm 0,3$ \\
\hline Оптимальне & $28,3 \pm 0,5$ & $319,1 \pm 5,8$ & $4,2 \pm 0,2$ & $8,5 \pm 0,4$ \\
\hline $\mathrm{F}$ & 0,7 & 0,8 & 5,6 & 3,7 \\
\hline $\mathrm{p}$ & 0,49 & 0,44 & 0,01 & 0,03 \\
\hline
\end{tabular}

Розрахунок комплексного показника харчування учнів дозволив встановити, що інтегральна оцінка споживання корисних продуктів учнями середнього шкільного віку становить $(81,3 \pm 0,8) \%$, старшого шкільного віку - $(78,7 \pm 1,9) \%$. Виявлено, що цей показник у 9-тикласників значно менший, ніж у 5-тикласників ( $\mathrm{t}=2,0$; $\mathrm{p}<0,05)$, при цьому статевих відмінностей режиму споживання корисних продуктів не виявлено у жодній групі дослідження $(p>0,1)$.

Інтегральна оцінка нерекомендованих продуктів та напоїв у старшокласників значимо вища, ніж в учнів середнього шкільного віку $(56,5 \pm 2,6) \%$ проти $(46,5 \pm$ $1,5) \%$ відповідно $(t=3,1$; $p<0,01)$, що $є$ позитивною тенденцією.

Розрахунки показали, що за комплексною оцінкою харчування $(13,6 \pm 1,8) \%$ дітей середнього шкільного віку мають оптимальне харчування, $(67,8 \pm 2,4) \%$ - задовільне, $(18,6 \pm 2,0) \%$ - незадовільне. 3 5-го по 9-й клас зростає частка дітей 3 незадовільним харчуванням та зменшується - $з$ задовільним та оптимальним $\left(r_{\mathrm{s}}=0,17 ; \mathrm{p}<0,001, \chi^{2}=12,7\right.$ $\mathrm{p}<0,05)$ (рис. 3).

Гендерні відмінності виявлено лише при аналізі анкет учнів 5-го $\left(\chi^{2}=8,9 ; p<0,01\right)$ та 7-го класів $\left(\chi^{2}=7,4 ; p<0,05\right)$. Серед хлопчиків 5-го класу частка дітей 3 незадовільним харчуванням становить $(20,3 \pm$ $5,5) \%$, а серед дівчаток - $(3,2 \pm$ $2,2) \%$. Відповідні показники градації «оптимальне харчування» становлять $(13,0 \pm$ $4,6) \%$ серед хлопчиків і $(19,1 \pm$ $5,0) \%$ серед дівчаток. У учнів 9 го та 10-го класів показники дівчат та хлопців між собою статистично не відрізняються $(p>0,1)$

Кількісна характеристика розумової працездатності, тобто обсяг роботи, статистично не відрізняється при різному харчуванні ( $p>0,05)$, хоча спостерігається тенденція до її підвищення при оптимальному рівні порівняно з незадовільним та задовільним. Проте визначено статистично підтверджене підвищення якісної складової працездатності (тобто зменшення помилок) 3 покращанням харчування $(p<0,05)$ (табл. 2). Ізольований вплив фактора 
«харчування» на продуктивність розумової працездатності становить $(7,3 \pm 0,4) \%$ $(p<0,01)$.

Також встановлено зв'язок підвищення продуктивності працездатності з підвищенням інтегральної оцінки харчування $\left(r_{s}=0,12 ; p<0,001\right)$.

Встановлено вплив фактичного харчування учнів на ступінь розвитку втоми під час навчального процесу. 3 метою розрахунку відносного ризику впливу харчування на розвиток втоми вказані в анкеті продукти та страви було розподілено на дві групи за гігієнічною оцінкою задовільно/незадовільно.

При незадовільному харчуванні частка дітей 3 високою мірою стомлення становить (72,3 $\pm 2,7) \%$, при оптимальному - $(55,1 \pm 7,0) \%$. Ймовірність високого рівня стомлення в 1,3 рази вища за незадовільного харчування, ніж при задовільному $(R R=1,33$; ДІ 1,03-1,75; $p<0,05)$.

\section{Висновки}

1. Фактичне харчування сучасних підлітків характеризується недостатнім споживанням таких продуктів, як м'ясо, вершкове масло, яйця та молоко у $22 \%$ учнів, риби та морепродуктів - у $60 \%$ учнів. Загалом незадовільне харчування характерне для 19\% учнів середнього шкільного віку та $16 \%$ - старшого.

2. За період від 5-го до 9-го класу у 2,5 рази збільшується кількість дітей з незадовільним харчуванням $(p<0,001)$.

3. Встановлено, що учні 3 оптимальним харчуванням роблять менше помилок під час розумової роботи.

Ізольований вплив фактора «харчування» на продуктивність розумової працездатності становить $(7,3 \pm 0,4) \%$ $(\mathrm{p}<0,01)$.

4. Встановлено вплив фактичного харчування учнів на ступінь розвитку втоми під час навчального процесу. Имовірність високого рівня втоми учнів в 1,3 рази вища при незадовільному харчуванні, ніж при задовільному $(p<0,05)$.

ЛІТЕРАТУРА

1. Сердюк А.М., Полька Н.С., Єременко Г.М., Сисоєнко Н.В., Селезньова К.І. Гігієнічні проблеми збереження здоров'я дітей у сучасних умовах реформування освіти в Україні. Гігієна населених місць : зб. наук. пр. Київ, 2004. Вип. 43.

C. 402-406.

2. Куликова Н.В., Самолюк Н.Г., Федотов А.С., Кротенко Н.М. Рационализация питания школьников разных возрастных групп. Гигиена и санитария. 2013. № 2. C. 52-54.

3. Шкуро В.В., Корзун В.Н. Пищевой статус младших школьников Украины и пути его оптимизации

Гігієна населених місць : зб. наук. пр. Київ, 2007. Вип. 50. С. 291-295.

4. Федоренко В.І., Москвяк Н.В. Гігієнічна оцінка середньодобового набору продуктів молодших школярів. Гігієна населених місць : зб. наук. пр. Київ, 2007. Вип. 49. С. 353-357.

5. Платонова А.Г. Вкусовые пристрастия и предпочтения в питании современных школьников. Формирование здорового образа жизни школьников в современных условиях : тезись Международной конф. стран ВЕЦА (14-15 ноября 2016 г., Москва). Москва,

2016. C. 79 .

6. Wilson B. Many English Schoolchildren Have a Nutritionally Deficient Diet. New Statesman. 2002. Vol. 131 № 4602. P. 40.

7. Антропова М.В.

Работоспособность учащихся и ее динамика в процессе учебной и трудовой деятельности. М. : Просвещение, 1967. $251 \mathrm{c}$

8. Антомонов М.Ю.

Математическая обработка и анализ медико-биологических данных. К., 2006. С. 451-464.

REFERENCES

1. Serdiuk A.M., Polka N.S., Yeremenko G.M., Sysoenko N.V. and Selezniova K.I. Hihienichni problemy zberezhennia zdorovia ditei v suchasnykh umovakh reformuvannia osvity v Ukraini [Hygienic Problems of Children's Health Preservation under Modern Conditions of Education Reformation in Ukraine]. In : Hihiiena naselenykh mists: $z b$. nauk. prats [Hygiene of Settlements]. Kyiv ; 2004 ; 43 : 402-406 (in Ukrainian).

2. Kulikova N.V., Samoliuk N.G., Fedotov A.C. and Krotenko N.M. Gigiiena sanitariia. $2013 ; 2$ : 52-54 (in Russian).
3. Shkuro V.V. and Korzun V.N. Pishchevoi status mladshykh shkolnikov Ukrainy i puti yego optimizatsii [Food Status of Junior Schoolchildren of Ukraine and Ways for its Optimization]. In : Hihiiena naselenykh mists: $z b$. nauk. prats [Hygiene of Settlements]. Kyiv ; 2007 ; 50 : 291-295 (in Ukrainian).

4. Fedorenko V.I. and Moskviak N.V. Hihiienichna otsinka seredniodobovoho naboru produktiv molodshykh shkoliariv [Hygienic Assessment of Average Daily Set of Products in Junior Schoolchildren]. In : Hihiiena naselenykh mists: $z b$. nauk. prats [Hygiene of Settlements]. Kyiv ; 2007 ; 49 : 353-357 (in Ukrainian).

5. Platonova A.G. Vkusovyie pristrastiia I predpochteniia v pitanii sovremennykh shkolnikov [Taste Liking and Preferences in the Nutrition of Modern Schoolchildren]. In : Formirovaniie zdorovogo obraza shizni shkolnikov $v$ sovremennykh usloviiakh : tezisy konf. [Forming of Healthy Life Style of the Schoolchildren under Modern Conditions: Theses of Conf.]. Moscow ; 2016 : P.79

(in Russian).

6. Wilson B. New Statesman. 2002 ; 131(№ 4602) : P. 40.

7. Antropova M.N.

Rabotosposobnost

uchashchikhsia i yeye dinamika v protsesse uchebnoy i trudovoy deiatelnosti [Working Capacity and its Dynamics in the Process of Educational and Labour Activity]. Moscow :

Prosveshcheniie ; 1967 : 251 p. (in Russian).

8. Antomonov M.Yu. Matematicheskaia obrabotka i analiz medico-biologicheskikh dannykh [Mathematical Processing and Analysis of Medico-Biological Data]. Kiev ; 2006 : 451-464 (in Russian).

Надійшла до редакції 18.04.2017 